gen receptors in lesional skin. However, previous hepatitis A infection was a casual finding in this patient, with antiHAV IgG, although the time of occurrence could not be specified, which might suggest triggered mosaicism as a possible cause, albeit challenging to confirm.

Disclosure. Financial support: none. Conflicts of interest: none

${ }^{1}$ Department of Dermatology,
Di.S.Sal., University of Genoa, San
Martino Polyclinic Hospital IRCCS,
Largo Rosanna Benzi 10, 16132
Genoa, Italy
${ }^{2}$ Section of Pathology, University of
Genoa, San Martino Polyclinic
Hospital IRCCS, Largo Rosanna
Benzi 10, 16132 Genoa, Italy
<emanuele.cozzani @ unige.it>

Micalizzi CLAUDIA ${ }^{1}$ Herzum ASTRID ${ }^{1}$ Emanuele COZZANI ${ }^{1}$ Francesco CABIDDU ${ }^{2}$ Antonio GUADAGNO ${ }^{2}$ Aurora PARODI ${ }^{1}$

1. Blaschko A. Teleangiektasien. Versammlungen. Berliner Dermatologische Gesellschaft. Monatschr Prakt Dermat 1899; 28: 451.

2. Zeisler EP. Telangiectasia associated with syphilis and pregnancy. Arch Dermatol 1922; 5:781

3. Karakaș $M$, Durdu $M$, Sönmezoğlu $S$, Akman $A$, Gümürdülü $D$. Unilateral nevoid telangiectasia. J Dermatol 2004; 31 : 109-12.

4. Wenson SF, Jan F, Sepehr A. Unilateral nevoid telangiectasia syndrome: a case report and review of the literature. Dermatol Online J $2011 ; 17: 2$

5. Lang $N$, Happle R, Enk AH, Haenssle HA. Unilateral nevoid telangiectasia in two adolescents. J Dtsch Dermatol Ges 2017; 15: 660-2.

6. Wilkin JK, Smith JG Jr., Cullison DA, Peters GE, Rodriquez-Rigau LJ, Feucht CL. Unilateral dermatomal superficial telangiectasia. Nine new cases and a review of unilateral dermatomal superficial telangiectasia. J Am Acad Dermatol 1983; 8: 468-77.

7. Tanglertsampan C, Chanthothai J, Phichawong T. Unilateral nevoid telangiectasia: case report and proposal for new classification system. Int J Dermatol 2015; 52: 608-10.

8. Guedes R, Leite L. Unilateral nevoid telangiectasia: a rare disease? Indian J Dermatol 2012; 57: 138-40.

9. Uhlin SR, McCarty KS. Unilateral nevoid telangiectatic syndrome. The role of estrogen and progesterone receptors. Arch Dermatol 1983; 1 19: 226-8.

10. Tașkapan $O$, Harmanyeri $Y$, Sener $O$, Aksu A. Acquired unilateral nevoid telangiectasia syndrome. Acta Derm Venereol 1997; 77: 62-3.

doi:10.1684/ejd.2020.3867

\section{Mild therapeutic response of alopecia areata during treatment of psoriasis with secukinumab}

Psoriasis is a chronic disease characterized by erythematous, scaly, and hyperkeratotic plaques that can extend all over the skin. Psoriasis is widely recognized to diminish quality of life, especially when sensitive areas, such as genitals, are involved [1]. Basic research and several clinical trials have suggested a dominant role of interleukin 17A (IL-17A) in the pathogenesis of psoriasis [2].
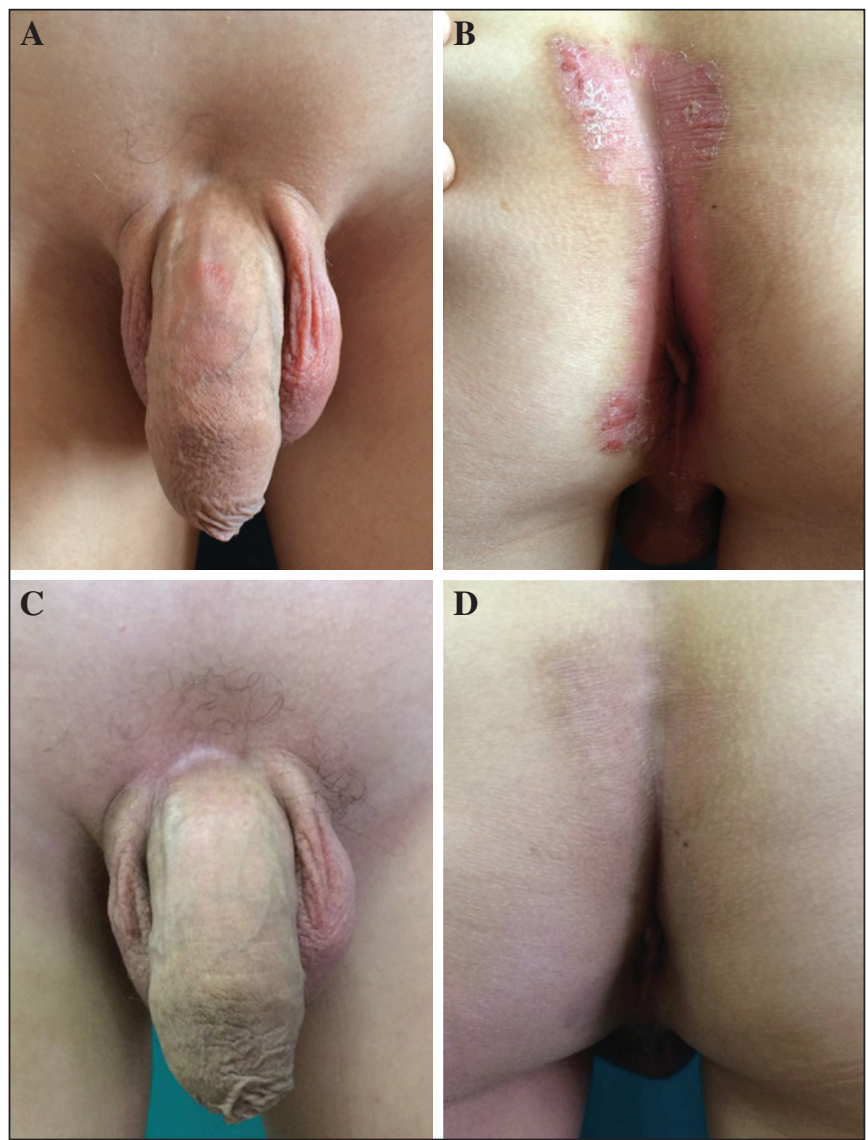

Figure 1. Genitals and intergluteal area before $(\mathbf{A}, \mathbf{B})$ and after treatment $(\mathbf{C}, \mathbf{D})$.

Alopecia areata, characterized by non-scarring hair loss [3], is also considered to be a T-cell-mediated disease [4]. It is usually classified into three groups according to the extent of the disease: (1) well-demarcated patches of hair loss, which is the most common form; (2) complete absence of hair on the scalp, known as alopecia totalis; and (3) total loss of hair all over the body, known as alopecia universalis [3]. We report the case of a 42-year-old male presenting in June 2016 at our outpatient clinic with a 25-year history of alopecia universalis and a two-year history of psoriasis. He had complete loss of hair all over the body. The alopecia was treated with topical steroids only at the onset, for about one year without benefit; no further treatments were undertaken, nor was an improvement of the disease observed over time. In the last two years, he developed psoriasis, also involving the genitals (figure $1 A, B$ ). At the time of observation, our patient had a score of 7 for the Psoriasis Area Severity Index (PASI) and 13 for the Dermatology Life Quality Index (DLQI). The patient had never used systemic drugs for psoriasis, but only topical medications, without any significant benefit.

In February 2017, the patient was started on subcutaneous secukinumab therapy at a dosage of $300 \mathrm{mg}$ per week for the first five weeks, followed by a maintenance period at $300 \mathrm{mg}$ per month.

In May 2017, the patient showed a decrease in PASI to 0 and decrease in DLQI to 1, with complete resolution of psoriasis at all body sites, including the genitals (figure 1D), with 
significant improvement in his quality of life. In particular, we noted a mild but significant increase in hair on the pubis (figure 1C), eyebrows, face, and scalp. The patient reported that the psoriasis began to improve after about 10 days of treatment, whereas the hair regrowth started after six weeks of therapy.

In November 2017, the patient, of his own accord, discontinued secukinumab therapy due to complete resolution of psoriasis, and at a follow-up visit, in March 2018, he showed an initial recurrence of both psoriasis (PASI 1.8) and alopecia. The patient has not yet restarted systemic treatment.

The efficacy of secukinumab for the treatment of psoriasis is well known [5]. Here, we report the effectiveness of secukinumab treatment on genital psoriasis and alopecia areata.

Interleukin-17 has been shown to be involved in the pathogenesis of various inflammatory and autoimmune conditions [6, 7]. A possible role for IL-17 ${ }^{+} \mathrm{T}$-helper cells in the pathogenesis of alopecia areata has been proposed [8], suggesting a rationale for the use of the IL-17 inhibitors in this disease.

A small double-blinded, randomized prospective pilot study found that no patients in either the secukinumab or placebo groups met the primary endpoint, consistent with a 50\% reduction in Severity of Alopecia Tool score (SALT50) at Week 24 [9]. Along with the possibility that Th17 is not pathogenic in alopecia areata, these authors hypothesized that the dose of secukinumab might have been insufficient, or the treatment duration too short to trigger the hair regrowth. Furthermore, the occurrence of alopecia areata has sometimes been reported among the side effects of some anti-interleukin drugs, including secukinumab and ustekinumab [10].

Although it is premature to draw any conclusion about the efficacy of secukinumab on alopecia areata based on a single case, both the improvement in hair growth upon secukinumab treatment and the recurrence of alopecia upon secukinumab discontinuation in our patient suggest a potential benefit of anti-IL-17 treatment in patients with severe and long-lasting alopecia areata, however, further and more extensive studies are needed to confirm this.

Disclosure. Acknowledgements: we thank Ray Hill, an independent medical writer, who provided medical writing support on behalf of Health Publishing \& Services Srl. This service was supported by Novartis Farma SpA. Funding: none. Conflicts of interest: none.

(C) The Author(s) 2020

Open Access. This article is licensed under a Creative Commons Attribution 4.0 International License, which permits use, sharing, adaptation, distribution and reproduction in any medium or format, as long as you give appropriate credit to the original author(s) and the source, provide a link to the Creative Commons licence, and indicate if changes were made. The images or other third party material in this article are included in the article's Creative Commons licence, unless indicated otherwise in a credit line to the material. If material is not included in the article's Creative Commons licence and your intended use is not permitted by statutory regulation or exceeds the permitted use, you will need to obtain permission directly from the copyright holder. To view a copy of this licence, visit http://creativecommons.org/licenses/by/4.0/.

${ }^{1} 1$ st Division of Dermatology,
Istituto Dermopatico
dell'Immacolata IDI-IRCCS, Rome,
Italy
${ }^{2}$ Istituto Nazionale per la
promozione della salute delle
popolazioni Migranti ed il contrasto
delle malattie della Povertà (INMP),
Via di San Gallicano 25/a. Rome,
Italy
$<$ g.pagnanelli@idi.it>

Gianluca PAGNANELLI ${ }^{1}$ Andrea CAVANI ${ }^{2}$ Flora CANZONA ${ }^{1}$ Cinzia MAZZANTI ${ }^{1}$

1. Yang EJ, Beck KM, Sanchez IM, Koo J, Liao W. The impact of genital psoriasis on quality of life: a systematic review. Psoriasis (Auckl) 2018; 8: 41-7.

2. Krueger JG, Wharton KA Jr., Schlitt T, et al. IL-17A inhibition by secukinumab induces early clinical, histopathologic, and molecular resolution of psoriasis. J Allergy Clin Immunol 2019; 144:750-63.

3. Strazzulla LC, Wang EHC, Avila L, et al. Alopecia areata: disease characteristics, clinical evaluation, and new perspectives on pathogenesis. J Am Acad Dermatol 2018; 78: 1-12.

4. Avitabile $S$, Sordi $D$, Garcovich $S$, et al. Effective squaric acid dibutylester immunotherapy is associated with a reduction of skin infiltrating T-helper (Th) 1 and Th 17 cells in alopecia areata patients. J Dermatol 2015; 42: 98-9.

5. Abrouk M, Gandy J, Nakamura M, et al. Secukinumab in the treatment of psoriasis and psoriatic arthritis: a review of the literature. Skin Therapy Lett 2017; 22: 1-6.

6. Maddur MS, Miossec P, Kaveri SV, Bayry J. Th 17 cells: biology, pathogenesis of autoimmune and inflammatory diseases, and therapeutic strategies. Am J Pathol 2012;181: 8-18.

7. Tanemura A, Oiso N, Nakano M, Itoi S, Kawada A, Katayama I. Alopecia areata: infiltration of Th 17 cells in the dermis, particularly around hair follicles. Dermatology 2013; 226: 333-6.

8. Ramot $Y$, Marzani B, Pinto D, Sorbellini E, Rinaldi F. IL-17 inhibition: is it the long-awaited savior for alopecia areata? Arch Dermatol Res 2018; 310: 383-90.

9. Guttman-Yassky E, Nia JK, Hashim PW, et al. Efficacy and safety of secukinumab treatment in adults with extensive alopecia areata. Arch Dermatol Res 2018; 310:607-14.

10. Yajima M, Akeda T, Kondo M, Habe K, Yamanaka K. Alopecia diffusa while using interleukin-17 inhibitors against psoriasis vulgaris. Case Rep Dermatol 2019; 11:82-5.

doi: $10.1684 /$ ejd.2020.3866

\section{A case of malignant melanoma of the areola in a male patient}

Pigmented lesions on the nipple and areola are rare and must be differentiated from malignant melanoma (MM), pigmented Paget's disease (pPD), benign melanocytic lesions and melanosis [1]. pPD is the most frequently described malignant tumour at this specific site [2]. Only few reports have described the dermoscopic findings of MM arising on the nipple or areola, and almost all cases have occurred in females [3-6]. We report a very rare case of MM that arose on a areola in a male, in which the dermoscopic findings facilitated the diagnosis. 